\title{
Het hart van de kerk
}

Gysbert Bos

Evangelische Theologiesche Faculteit

Heverlee, België

\section{Abstract}

\section{Het hart van de kerk}

The heart of the church

Abraham Kuyper accused the so-called 'ethische' theologians that they only pretended to be Calvinists because the doctrine of predestination did not figure as a central point of their thinking. In this paper the answer of $J$ H Gunning Jr, one of the leaders of the so-called 'ethischen', to Kuyper is discussed. Although this paper mainly focuses on six articles Gunning published in the periodical 'Stemmen voor waarheid en vrede' between 1878 and 1880, it also introduces other articles of Gunning into the discussion. The topic of this paper indicates how, in the end, Gunning saw predestination.

\section{INLEIDING}

In het blad Stemmen voor Waarheid en Vrede heeft J H Gunning jr in 1878 en 1880 in een zestal artikelen verantwoording afgelegd van wat hem en zijn medestanders bezielde, onder de titel Het ethisch karakter der waarheid. Eerst heeft hij prof J J van Oosterzee geantwoord op een aantal vragen, maar daarna is hij uitgebreid in discussie gegaan met dr A Kuyper. In beide gevallen komt eerst het gebruik van de naam of begrip 'ethisch' aan de orde. Men spreekt meer en meer van ethische theologie, van ethische richting of eenvoudigweg van ethischen. Gunning wil daar zo mogelijk een einde aan maken. Daarvoor heeft hij des te meer reden, als hij let op de wijze waarop Kuyper dit woord gebruikt. Dan is er geen sprake van een poging een objectieve aanduiding te hebben voor een aantal mensen, die onmiskenbaar een eigen manier van theologiseren bezigen maar ook op een speciale kritische wijze in de Hervormde Kerk staan.

Van Oosterzee probeert dit denken en doen te verstaan en heeft daarom zijn vragen gesteld in een open brief, waarvan hij een afschrift stuurde aan Gunning. Alleen al door (opnieuw) het gebruik van het woord 'ethisch' te verduidelijken hoopt Gunning nu deze vertegenwoordiger van een nieuwe vorm van supra-naturalisme te overtuigen van zijn tekort in theologische denken zonder daarmee zijn geloofsleven in gebreke te stellen. $\mathrm{Hij}$ is er zeker van, dat het weerwerk van de zogenaamde Utrechtse school niet in 
staat zal zijn werkelijk het modernisme op overtuigende wijze te bestrijden. Dat doet echter niets af van zijn waardering voor theologen als Van Oosterzee en Doedes ter zake van hun rechtzinnigheid en geloofsleven.

Wat dat betreft is Gunning altijd zeer voorzichtig in zijn uitlatingen, maar het is onmiskenbaar dat zijn discussie met Kuyper toch een andere toon heeft. De aanleiding daartoe is de wijze waarop Kuyper probeert Gunning en zijn medestanders te duiden. Er is niet slechts sprake van een noemen, waarbij op het woordgebruik eventueel aanmerkingen gemaakt kunnen worden. Nee, er is vanaf het begin sprake van een zelfs expliciete veroordeling door te spreken van de tegenstelling: ethisch - gereformeerd en vervolgens de zogenaamde ethische here in onderscheid met de gereformeerde broeders ervan te beschuldigen slechts voorgevend calvinist te zijn. Zijn gereformeerde volgelingen moeten heel goed weten dat deze mensen slechts in ethische zin de christelijke belijdenis zijn toegedaan. Volgens Kuyper ligt het gevaar daarin dat deze voorgangers door hun preken en spreken zoveel indruk maken op het kerkvolk, terwijl het niet door helft dat het in feite wordt misleid. Het is te begrijpen dat Gunning eigenlijk niet goed raad weet met het verzoek om vervolgens met ere en zonder wrevel, alleen om des beginselswille de discussie aan te gaan.

Hij meent oneerlijk behandeld te worden, maar is desondanks bereid om op de door Kuyper aangereikte punten nader in te gaan. De meeste aandacht vraagt de visie op de kerk met de te verwachten gevolgen voor het handelen in de strijd om het functioneren van Schrift en belijdenis in de Hervormde Kerk. Daaraan vooraf echter wil deze nadere uitleg over de ethische uitverkiezingsleer. Hij heeft de indruk, dat door Gunning cs de algemene verzoening geleerd wordt doordat de uitverkiezing niet centraal staat in het theologsch denken van de 'ethischen'. Gunning heeft ook daarom al moeite met de positie waarin Kuyper hem dringt tegenover de gereformeerden, omdat hij deze en andere principiële zaken zich absoluut niet een tegenstander voelt. Om dit duidelijk te maken is hij bereid om in een paar zinnen zijn belijden ter zake samen te vatten. We vinden dit antwoord in het derde artikel van de voornoemde serie.

Hij geeft toe dat hij dit geloofsartikel slechts zelden noemt, maar dat heeft zijn oorzaak in het feit dat het altijd verondersteld wordt en dat niet alleen in zijn theologiseren of prediken maar ook in zijn persoonlijk geloofsleven. 'Zoo ik mij niet door Gods vrije genade met alle kinderen Gods eeuwiglijk uitverkoren wist, ik zou geen ogenblik durven of willen leven' (Gunning 1880(III):286-287). Vervolgens geeft hij een nadere omschrijving: 'De kern dezer leer is, dat het gode behaagt, tot den zondaar, die in zichzelf met de gehele wereld doemschuldig en verloren is, in een levendmakende betrekking te treden' (Gunning 1880 (III):287). En deze betrekking is daarom zoo belangrijk, omdat daardoor pas de mens tot een persoonlijkheid wordt, die in vrijheid voor Gods aangezicht mag leven. 
Daardoor wordt de waarheid van de verkiezing betrokken op het hele leven van de mens. En dat is presies wat met het woord 'ethisch' bedoel wordt. De waarheid is ethisch.

\section{FUNDAMENTEEL EN PERSOONLIJK}

De consequentie daarvan is dat 'wij gelooven dat men bekeerd moet zijn om de waarheid te kunnen zien en over haar te kunnen spreken, hetzij als man der kerk hetzij als man der wetenschap' (Gunning 1878 (I):3). Alleen levend in relatie tot de Here God kan het hele leven van de mens in denken en doen tot zijn bestemming komen.

Hoe wezenlijk het leerstuk van de uitverkiezing ook voor Gunning is, tegelijk geeft hij toe dat hij de grond voor zijn bestaan niet op dezelfde wijze omschrijft als waarop Kuyper dat doet samen met de hervormers. Deze concessie van Gunning houdt overigens niet in, dat hij het met de kritiek van Kuyper eens is. Deze had gezegd dat Gunning dit leerstuk uit het hart van het geloof had weggehaald. Daartegenover verzekert Gunning dat hij uit volle overtuiging met de vaderen erkent dat de verkiezing het hart van de kerk is. In de voorrede van de brochure, waarin hij expliciet op deze geloofswaarheid ingaat: Van Calvijn tot Rousseau (Gunning 1881) zegt hij het als volgt: 'Deze leer is niet zoozeer een afzonderlijk leerstuk, dat als zodanig eenvoudig gelijk elke andere bijzonderheid, apart beschouwd, een voorwerp van uitlegkundig en dogmatisch onderzoek zou zijn. Neen, zij is een gezichtspunt, een geestrichting, een bepaalde wijze van de geheele waarheid van des evangelies aan te zien' (Gunning 1881: IV). Het is daarom de stil-zwijgende veronderstelling van alles wat men gelooft.

Hij heeft des te minder moeite met deze uitdrukking, omdat het hem de gelegenheid geeft voluit existentieel hierover te spreken. Dikwijls wordt bijna ongemerkt de verkiezing als het hart van de leer van de kerk gezien, waardoor er spoedig sprake is van een formeel beginsel van leer en leven met alle gevolgen van dien. Gunning ziet deze ontwikkeling al heel spoedig plaatsvinden. Hij wijst erop dat in het godsdienstgesprek te Montbeliard tegenover de luthersen 'de volstrekte voorbeschikking niet meer als eisch der persoonlijk-godsdienstige verzekerdheid maar als zelfstandige gevolgtrekking uit de objectieve Godsidee wordt gesteld' (Gunning 1881:36). Tegenover deze wijze van theologiseren stelt hij dat de verkiezing nu juist het persoonlijke in de ontmoeting van Göd en mens bedoelt uit te drukken. Het hart van de kerk is de plaats waar God en mens van hart tot hart met elkaar verkeren, waarbij de Here God het initiatief heeft. Het is de heerlijke levenservaring der praedestinatie, dat hart der kerk gelijk ik haar met de vaderen noem - of wel der waarheid dat God in onmiddellijke levendmakende aanraking wil treden met het binnenste zijner kinderen' (Gunning 1869: 60). Daarbij moet men bedenken, dat die plek een ontoeganklijk heiligdom is, waar 
alleen God toegang heeft (Gunning 1880(V):4). Dat maakt het voor een mens onmogelijk om te oordelen over de diepste bedoeling van een ander. Juist in de gemeente zou dat bekend moeten zijn, maar ook daar gaan discussie heel gemakkelijk over in diepgaande veroordelingen van de tegenstander zelf in plaats van te blijven bij wat hij zegt of doet.

Het is echter wel mogelijk om vanuit deze relatie met God, vanuit de positie van het geloof over de verkiezing zelf te spreken en dat heeft Gunning gedurende de vele jaren dat hij de gemeente mocht dienen als predikant of als hoogleraar, talloze keren gedaan. De ene keer omdat tegenstanders hem een verklaring afdwongen, de andere maal omdat gemeenteleden hem naar de troost van deze geloofswaarheid vroegen. En dikwijls ook gebeurde het enkel om te laten weten wat de Here God in zijn genade voor hem en alle gelovigen betekent. In dit artikel willen we de vele opmerkingen samevattend weergeven naar zijn diepe en brede betekenis. In Beker en Den Boer(1979) wordt kort ingegaan op dit onderwerp en in Graafland (1987) worden alleen de opvattingen van Gunning besproken naar aanleiding van het boekje Van Calvijn tot Rousseau (1881).

\section{BELIJDEND SPREKEN}

In de jaren negentig heeft Gunning veel geschreven in het blad Pniel van zijn zoon J H Gunning JHzn en daarbij gaat hij dikwijls in op vragen die gesteld werden op pastoraal vlak naar aanleiding van wat geschreven staat in de Bijbel of gezegd werd in de kerk. Op de vraag: hoe kom ik tot geloof en bekering, was eens geantwoord: begin maar met bidden al is het werktuiglijk. Daar zal beslist zegen op rusten en dan kan een mens het opmerken dat hij tot geloof gekomen is.

Gunning wil niet zeggen dat het zo niet kan gaan, maar hij heeft bezwaren tegen de achterliggende mening dat in feite alle geestelijke leven begint met bekering. Dan wordt uit het oog verloren dat de boodschap van Jesus Christus aan alle voorafgaat: 'Jesus is ook uw Heiland, daarom bekeer $u$ en geloof in hem, dan zal de Heilige Geest uw hart vernieuwen' (Gunning 1893:342). Het komt in principe altijd op gehoorzaamheid aan, terwijl het onderzoeken van gemoedstoestanden uiteindelijk geen zekerheid geeft. Achteraf zal gezegd worden: het is enkel Gods verkiezende genade. En dan kan ook over de verkiezing zelf nader inzicht verkregen worden. 'Wie over de Voorbeschikking wil redeneeren en nadenken voor hij gelooft, die kan er nooit over tot helderheid en rust komen' (Gunning 1893:342). 'Zij is niet een angstig raadsel - vooraf - Maar zij is de verrukte terugblijk van de geloovige op alles, wat hem tot aan dit punt, waar hij knielend in het stof aanbidt, is wedervaren' (1884:96). 
Dit inzicht gaat gepaard met persoonlijke zekerheid. Een paar jaar eerder schreef hij verschillende meditatieve stukken vol schrifuitleg in het blad Woorden des eeuwigen levens. En ook toen kwam dit onderwerp aan de orde. Naar aanleiding van Jobs uitroep: Ik weet dat mijn verlosser leeft, merkt hij op dat de waarheid van de verkiezing niet wil afschrikken maar veeleer vol verwondering doet terugzien naar een plan, een verkiezende liefde. 'En blijde zie ik dan ook, dat dit eeuwig blijven zal, omdat God getrouw is' (Gunning 1886:45-50). In een volgend artikel stelt hij voor de laatste woorden van Romeinen 8:28 te vertalen met: 'daar zij waarlijk naar zijn voornemen geroepen zijn'. Paulus' bedoeling is om een mens die God liefheeft, te bewaren voor de onzekerheid over het gehalte en de duur van die liefde.

Er is een goddelijk werk achter. Onze liefde tot God is antwoord op een roeping Gods, die tot ons kwam. En deze roeping Gods was wederom gevolg van een voorverordening, een beschikking van God over ons leven en onze lotgevallen, waardoor alles zoo samengevoegd stond, dat wij van God geroepen werden'.

(Gunning 1887:172)

In deel IV van de Blikken in de Openbaring is er alle gelegenheid om deze zienswijze te onderbouwen. Hierin laat Gunning zien, hoe de persoonlijkheid van de nieuwtestamentische bijbelschrijvers mede bepalend is voor de vormgeving van evangelie of brieven. De bekering van Paulus vernietigde zijn gehele bestaan, dat hij meebracht, zoals dat ook in de doop bevestig werd. En toen God hem oprichte, heefte hij als het ware de woorden gehoord, die heel zijn leven bij hem gebleven zijn: 'Ja, inderdaad, uw leven hangt gansch en al aan Mijn welbehagen alleen, maar dat welbehagen is ontferming, levendmakende liefde' (Gunning 1869(IV):105). En in al zijn brieven klinken deze woorden door.

Petrus roept ertoe op om 'uw roeping en verkiezeing te bevestigen' (2 Petrus 1: 10). Dat betekent niet, dat een mens door redeneringen en bijeenbrengen van teksten tot een konklusie kan komen uitverkoren te zijn. 'Neen, hier geldt het, dien heilige levensernst te betoonen, waarbij de mensch, al verder voortgaande in de oefening van allerlei deugd, in dezelfde mate al meer en meer overtuigd wordt dat hij niets, niets in zichself vermag en enkel van goddelijke, verkiezende genade kan leven' (Gunning 1869 (IV):279). Zo leert men Christus kennen in zijn volheid. En in Hem ook zichzelf en elk terrein des levens met alle gevolgen voor echte wetenschapsbeoefening. 


\section{GEREFORMEERD EN OECUMENISCH}

Wanneer Gunning zich beroept op het gevoelen der 'vaderen', dan bedoelt hij met name de gereformeerde vaderen. In de kern van het belijden waren Luther en Calvijn het eens, want de rechtvaardiging uit het geloof zonder de werken èn het leven uit Gods vrije, verkiezende genade betekent hetzelfde. Beide kunnen 'de hoogste uitdrukking der waarheid' genoemd worden (Gunning 1882:322-323).

Toch is er dit verschil tussen de twee genoemden: Calvijn vraagt niet alleen naar de rechtvaardiging van de zondaar, naar vervolgens ook naar het leven in Gods gemeenschap. En dat heeft gevolgen voor het kerkelijke leven, zodat het van grote betekenis is geweest voor de reformatie, dat Calvijn na Luther gekomen is. Maar hen verbond het grote protestantse belang: 'de dadelijke gemeenschap met God zonder belemmering door enige menschelijke of ander middelaarschap' (Gunning 1881:10), of zoals hij het eerder schreef: 'De waarheid der eeuwige verkiezing is in de grond niets anders dan dat God met het diepste van 's menschen wezen in een onmiddellijke levende betrekking treedt, hem bij name roept' (Gunning 1869 (III):141). Deze visie eist vanzelf een Godsidee zoals die in de later meer ontwikkelde leer der verkiezing tot uitdrukking komt, zodat de zoeven genoemde waardering in de kern de verkiezingsleer geldt: 'om deze buitengewone diepte waarin de fundamenten der Gereformeerde Kerk gelegd zijn, kan ik dan ook niet nalaten, haar wat hare kern betreft, voor de hoogste uitdrukking der waarheid te houden' (Gunning 1863:35).

Daarmee keert men zich tegen elke vorm van middelaarschap die op de een of andere manier God en mens uit elkaar houdt. Dan wordt automatisch gedacht aan Rome maar ook in protestantse kring wordt het middelaarschap van Christus niet altijd juist gezien. En ten diepste gaat dárover het geding dat de zogenaamde ethische theologie heeft met zijn verschillende tegenstanders!

Tegelijk wordt hiermee benadrukt dat het behoud enkel genade is, omdat de mens niets meebrengt dan zichzelf. En hij heeft nu eenmaal geen leven in zichzelf. Hij is doemschuldig en verloren (Gunning 1880 (III):287). De leer der verkiezing predikt om te beginnen verdoemelijkheid en dood (Gunning 1865:10), zodat er geen enkele reden is om Gunning cs te beschuldigen van een verdoezelen van de werkelijkheid van de zonde.

In het vierde artikel van de eerder genoemde serie Het etisch karakter der waarheid gaat hij nader op de etiek van Kuyper. Daarbij bepaalt hij zich met de Schrift tot het tekenen van de religieuze ervaring. Daarmee bedoelt hij de onderwijzing die de Heilige Geest aan de gemeente geeft.

Het alternatief is om volgens de wetten der logica een filosofisch systeem aan te reiken. Deze pogingen zullen echter altijd stuk lopen op de werkelijkheid van de zonde van de mens. Later heeft hij dit in de discussie met de opvattingen van Spinoza nader uiteengezet (Gunning 1903 en vgl Spinoza 1876). Het aantrekkelijke van deze leer is 
dat alles op een indrukwekkende manier samenhang vertoont, waarbij God de hele werkelijkheid doorstraalt met zijn krachten (pantheisme). Het is een geweldig visioen dat veel belooft en voor het heden zeer aantrekkelijk is - meer dan het deisme. Het weet alleen geen raad met het kwaad als schuld. En dát is nu wat het geweten niet kan en wil ontkennen, hoewel de machteloosheid om goed te doen een goede reden zou kunnen zijn om schuld te verwerpen.

De conclusie: onmacht is schuld, die dan wel logisch ongerijmd is maar tegelijk onontkoombaar voor ons geweten, bewijst de verschrikkelijke werkelijkheid van de zondeval. Een aantal keren heeft Gunning opgemerkt, dat het aanvaarden van de erfzonde als persoonlijke schuld de meest heroïsche daad is die een mens kan volbrengen. Het is de erkenning van een noodzakelijkheid, waaraan een mens onderworpen is zonder deze aan God toe te schrijven. Daarmee aanvaardt hij zijn wortels te hebben in het geheel van de aardse werkelijkheid tot op het allereerste begin. Zo betuigt hij zijn achting voor zijn hoofd Adam èn via hem voor de hele natuur. En wanneer hij deze betrokkenheid niet als een noodlot, maar als ook zijn eigen schuld aanvaardt, heeft hij in beginsel zijn persoonlijkheid gered. Maar dat is feitelijk alleen mogelijk, wanneer hij mag zien op dat andere hoofd, de tweede Adam, die eerder was, omdat Gods schepping van eeuwigheid op Hem gegrond is. Wie in het geloof ziet op Hem die aan zijn schepping heeft vastgehouden tot in het oordeel van de godverlatenheid, zal met Hem mogen leven in het licht van de gemeenschap met God met hèl zijn geredde bestaan (Gunning 1869:105; 1876:1-28; 1881:427; 1886:86).

Logisch is dit ongerijmd, maar dat betekent alleen dat we afstand zullen moeten nemen van elk filosofisch systeem dat op logische wijze onze werkelijkheid verklaren wil. Natuurlijk zal er sprake zijn van samenhangen en inzicht daarin en in de dogmatiek proberen we een begin te maken met het natekenen van die samenhang in gehoorzaamheid aan de Schrift. Echter alleen wanneer het kwaad overwonnen is, zal het mogelijk zijn te verstaan wat zijn plaats in het geheel van Gods schepping geweest is. Daarop anticiperen met een logisch systeem betekent altijd of het kwaad ontkennen of het wettigen (Gunning 1903:80), waarbij overigens aan onze werkelijkheid tekort gedaan wordt. Het hart van de mens echter, dat moest bukken voor deze werkelijkheid en vervolgens op de prediking van genade in Christus levend is gemaakt, mag 'bij het licht des Woords zijn ervaringen beschrijven door hier en daar punten aan te stippen, wier systematiseering voor de eeuwigheid bewaard blijft' (Gunning 1880 (IV):427). Daarbij heeft zij genoeg aan Christus en aan de Schriften die van Hem getuigen. Tegenover het bekende adagium van Descartes stelt Gunning: 'Ik besta, omdat ik verlost ben, want ik had al lang de eeuwige verdoemenis verdiend' (Gunning 1869 (III): 136). 
Dit heeft niet alleen gevolgen voor het theologiseren maar ook voor het leven der gelovigen in het omgaan met de wereld en vooral in relatie met anderen in de brede kerkelijke gemeenschap. Wat het eerste betreft: 'Het verkiezingsgeloof is de diepe, volstrekte onderwerping aan Gods reddende Genade, en daardoor de bron der zelfstandigheid die den heldenmoed onzer Vaderen verklaart' (Gunning 1903:83).

Het tweede is in dit verband belangrijker. Op grond van de belijdenis der verkiezing als boven omschreven kan een protestant open staan voor anderen. Hij kan zijn eigen eenzijdigheid zien èn erkennen in tegenstelling met de roomskatholiek (Gunning 1882:332). En daarom moet een calvinist in het oecumenisch gesprek juis calvinist blijven. Om dezelfde reden hecht Gunning eraan gereformeerde genoemd te worden. Met hart en ziel hangt hij het calvinistische geloofstype aan omdat het 'meer dan eènige andere uiting van het Reformatorische leven, het karakter der voorlopigheid, dat aan de geheele Hervorming eigen is, handhaaft en den eisch der katholiciteit, der ènheid van de geheele Kerk van allen die in den Driemaal Heiligen Naam gedoopt is, doet gelden' (Gunning 1867:13). Daarin waren zij ook ruimhartiger dan de lutheranen, omdat dezen de werking van Gods Geest zo nauw bonden aan het woord en het sacrament (in verbo), dat daarin zelfs een mogelijkheid gevonden werd orn te beoordelen of die ander van genade leeft.

Aangezien de gereformeerden benadrukken dat de Geest met het Woord werkt, stellen zij zich in dezen meer terughoudend en milder op. 'Alleen voor zichzelven is hij in staat en verplicht, over zijn eeuwig lot naar innerlijke ervaring uitspraak te doen' (Gunning 1880 (III):288). Maar daaraan voegde hij eens toe:

Wanneer ik mij baad aan den rand van den oceaan der eeuwige verkiezende vrije genade Gods, en dus het meest bepaald gereformeerd ben, dan voel $\mathrm{ik}$ mij onweerstaanbaar gedrongen om allen, allen, allen aan het hart te drukken, Luthersen, Doopgezinden, Remonstranten, Roomschen, in wie slechts ènig leven Gods bemerkbaar is, in wie de heerlijkheid van Hem dien ik mijn Heer en mijn God noem, zich ook maar enigszins, hoe aanvankelijk ook weerspiegelt. Daar is geen sterker prikkel tot eene allen-omvattende liefde, dan het besef van uit eeuwige ontferming in Christus uitverkoren te zijn.

(Gunning 1863:35)

Hij voelt zich echter gedrongen toe te geven dat zijn zienswijze ten aanzien van de verkiezing niet voldoende is om gereformeerd te heten. Over het algemeen heeft hij daar 
geen pijn aan geleden, omdat het hem er niet om ging door Kuyper en de zijnen aanvaard te worden. Meer ingrijpend is natuurlijk, dat hij moet toegeven, dat hij ook met Calvijn niet op èen lijn blijkt te zitten.

Daarbij mag om te beginnen nog eens onderstreept worden, dat hij het in principe met de hervormer van Genève van harte eens was. Maar ook in diens vormgeving van deze geloofswaarheid komt de zoeven genoemde voorlopigheid van het calvinisme tot uitdrukking. Tegenover de roomse uitwendigheid en werkheiligheid moest hij zich wel terug trekken op het hart van het geloof dat weet van Gods rechtmatige overmacht ter zake van de toekomst van de zondaar die het oordeel van God verdient heeft (Gunning 1869 (II): 102).

Hieraan voegde hij eens toe:

Men bedenke hoe Kalvijn's meer verfoeid dan met de eerbiedige aandacht die het verdient, overwogen "decretum horribile" strekte om de teederste, diepste belangen des geestelijken levens te beschermen tegen een deïsme waarin zoo niet de Lutheranen dan toch zeker de Arminianen door sociniaansche beperking van Gods almacht gevallen zijn.

(Gunning 1879:168)

Nadat dit gezegd is, moet vervolgens ook eerlijk opgemerkt worden dat er reden tot kritiek is op verschillende uitspraken van deze reformator. Hij meende kennelijk in deze situatie van voorlopigheid zijn leer nader te kunnen ontvouwen, waarbij hij volgens Gunning bleef op het niveau waarop het deïsme en determinisme het denken bepaald. In zijn boek Van Calvijn tot Rousseau heeft hij gepoogd de gevolgen van dit denken nader te ontleden en daartegenover God te schilderen als de almacht der liefde met alle gevolgen van dien. Daarbij verwerpt hij herhaaldelijk het verwijt dat hij de gereformeerde leer verzacht of uitholt.

Nee, er is veeleer sprake van een voortgaan op de weg van het kennen van de waarheid, waardoor de oorspronkelijke geloofswaarheid alleen maar meer zijn recht krijgt en daardoor des te belangrijker en rijker wordt voor het leven van de gemeente. Gunning meent zodoende in de geest van Calvijn verder te gaan. Er is dan ook geen sprake van, dat hij met zijn opvattingen Arminius nadert. Er wordt daarentegen des te duidelijker dat het remonstrantisme terecht is afgewezen. Ook Arminius denkt in het kader van (in)determinisme, waarbij het willen van de èn per definitie ten koste gaat van dat van de ander. Het gevolg is dat het verwijt van fatalisme, dat altijd weer aan de gereformeerde verkiesingsleer wordt gehangen, veeleer het arminianisme treft. De 
vrijheid van de mens wordt enigzins beperkt door de invloed van God en daarmee wordt subjectiviteit en onzekerheid alle ruimte gegeven. Opgelegde regels voor denken en handelen geven aanvankelijk nog enig houvast, maar het einde is altijd het anarchisme in de kerk en vervolgend in de maatschappij (Gunning 1881:88; vgl Gunning 1894).

\section{DE ALMACHT VAN DE DRIEËNIGE}

Wij mogen echter weten, dat ons bestaan niet ligt in Gods willen en doen maar in zijn wezen, waardoor er ruimte komt voor liefdevolle almacht, die raad weet met de zonde en respect heeft voor de vrijheid van zijn schepsel. 'God is de God der verkiezing, dat is: der barmhartigheid; want 'verkiezen' is in de Schrift niet dat marmerkoud willen en niet willen, begunstigen en verwerpen, dat de menschen ervan gemaakt hebben, maar het is het kiezen (Hebr. bachar) waarmee de jongeling in de liefde zijns harten zich zijne bruid kiest' (Gunning 1892:271; vgl Gunning 1888:143). En deze bruidegom is de Drieënige God zelf. Het kennen van deze God maakt het alleen maar mogelijk om op de juiste wijze het abstracte kennen van het verstand op te heffen in de taal van het hart. Nu kan niet alleen de discussie met het deisme overstegen worden, maar ook de confrontatie met het pantheisme worden aangegaan, hetgeen in de vorige eeuw van het allergrootste belang is geweest maar waar ook de kerk van onze tijd niet omheen kan. Gunning is als leerling van de filosoof Opzoomer diep onder die indruk geweest van deze zienswijze op onze werkelijkheid, die het rationalisme te boven gaat. Anderzijds was hij er meer en meer van doordrongen dat het de waarheid te kort doet. Waar ligt echter het punt van uiteen gaan? Op een kritiek moment in zijn nog jonge leven ontdekte hij dat de werkelijkheid van de zonde als schuld in deze visie geen plaats kan krijgen. Maar vervolgens werd het hem duidelijk dat het geschil gaat over de almacht van God. De grote vertegenwoordiger van het pantheïsme Spinoza 'leert: de almacht waarmee God werkt, is slechts een andere naam voor zijn wezen in zijn actualiteit, werksaamheid. Want Spinoza kent alleen Gods macht, of liever zijn kracht. En deze kracht werkt dadelijk, gestadig, altoos op dezelfde wijze, immers een persoonlijke keuze, een bewuste wil, is daar niet achter' (Gunning 1903:83). Dat is een uitkomst voor die mens, die voor zijn geweten op de vlucht is. Hij kan het idee krijgen dat hij aan de goddelijke besturing der wereld genoeg heeft en daarvoor hoeft hij niet te voorschijn te komen vanachter het geboomte in zijn paradijs. Afgezien van het feit, dat een mens daar uiteindelijk geen rust vindt, omdat hij zijn geweten heeft meegenomen, is het ook niet nodig zo te leven. De Drieënige God die ons bij name roept, is in staat om zijn beoogde doel met de schepping te bereiken door ruimte te scheppen voor de vrije persoonlijkheid van de mens door zijn almacht der liefde. En deze rijke boodschap van liefdevolle en bevrijdende genade vindt zijn uitdrukking in het leerstuk der 
Gunning is er zich van bewust dat hij hiermee niet alle facetten van Gods almachtig handelen genoemd heeft. Er zijn immers drie verschillende terreinen in het geheel van Gods schepping - namelijk de natuur, de geschiedenis en de gemeente - die elk op een eigen manier op Gods handelen zijn aangelegd. Met het begrippen-materiaal dat de zuidduitse filosoof Franz von Baader (1565-1841) hem aanreikte, spreekt hij vervolgens van respectievelijk doorwonen, bijwonen en inwonen (Gunning 1869 (I):42 en 1869 (II):372). Aangezien geen schepsel leven heeft in zichzelf, is er geen schepsel zonder dat God aan hem het leven geeft van dag tot dag. Dat geldt ook voor de toestand van Godverlatenheid, omdat deze inhoudt dat God niet met zijn liefde in ons woont, 'De groote vraag is, of de heiligheid Gods buiten u zij, tegenover u staande met hare beschuldigende stem, dan wel of $\mathrm{zij}$ in $\mathrm{u} z \mathrm{ij}$ als uw levensbeginsel .... Zoolang gij niet bekeerd zijt, staat de heiligheid Gods tegen u over en verklaart u schuldig. Schuld en ellende nu gaan altijd te zamen'(Gunning 1904:77).

Wanneer God in ons woont is er sprake van geestelijk leven. Dan verenigt Christus als bruidegom zich met de bruid en daarmee zijn alle dingen over en weer gemeenschappelijk. Wanneer de mens zich zo aan God vastklampt, is hij geheel Gods werk en dat houdt in dat heel zijn leven zijn eigen werk geworden is. Het is immers een leven in vrijheid.

In het hoofdstuk: God de schepper der vrijheid (Gunning 1869 (II):313-392) heeft hij uitgebreid deze zienswijze uiteen gezet in discussie met Spinoza die meende, dat bepaaldheid altijd beperking inhoudt. Dat geldt alleen, zo antwoordt Gunning, ter zake van natuurlijke relaties.

Het werken of plaatsnemen van de è̀n gaat dan altijd ten koste van de ander. In de geestelijke verhoudingen is dat niet waar en tot dat leven is de mens als de kroon van de schepping geroepen. Wanneer we daarbij bedenken dat dit schepsel van nature het meest bepaalde, het allerbehoeftigste wezen is dat in hulpeloosheid met niets te vergelijken is, dan verstaan we welk een wonder God in deze relatie tot stand brengt. Daartoe heeft Hij zich van eeuwigheid bepaald. En daardoor is de mens van eeuwigheid getekend. 'God kent geen andere keuze dan de keus der verkiezing, (Gunning 1869 (II):357). En het gevolg voor de mens is de mogelijkheid van het zachte juk der liefde.

Gunning is er zich diep van bewust wat het vraagt van de gemeente om dit te kennen en te belijden. 'Deze leer toch onderstelt een heilig sterk geestelijk leven; anders is zij veel te zwaar om te dragen, (Gunning 1881:36). Wanneer dit geestelijk leven verzwakt, is het niet te voorkomen dat de leer ook verswakt en aangepast word. Dat kunnen we herhaaldelijk zien in geschiedenis van de gemeente. Vervolgens toont de dogmatiek dat het denken het geweten tegemoet komt en poogt de situatie aannemelijk te maken. Na de Reformatie begon dat in de Nederlanden met het werk van Arminius en deze ontwikkeling is doorgegaan ondanks de synode van Dordrecht. 
Het is te verwachten dat Gunning geen heil ziet in het slechts terug grijpen op de oude gereformeerde dogmatiek of op een aangepaste formulering van de oude geloofswaarheden in confrontatie met nieuwe gevaren. Daarmee wordt de oorzaak van een verkeerde ontwikkeling niet weggenomen en zal deze hooguit enigszins opgehouden worden. Waar het op aankomt is het herstel van het geestelijk leven der gemeente. Dat is met andere woorden: een nieuw komen van de Drieënige God in het hart van de gemeente. Dat is nog steeds mogelijk, omdat bij God sprake is van een voortdurend scheppen. Paulus mag volkomen terecht in Romeinen 8, 29.30 het verkiezend handelen van God in verschillende momenten ontleden vanuit de ervaring van het geroepen zijn terug tot de eeuwige bestemming en vooruit tot aan de verheerlijking, maar hiermee wil geen tijdsbepaling aangeduid zijn. De verkiezing is immers eeuwig en dat wil zeggen van de tijd onafhankelijk.

God vindt niet als het ware den' mensch als vòr meer dan duizend eeuwen in Zijn gedachten voorhanden om dan, de massa schiftende, voor ieder de ontzaglijke handbeweging naar rechts of links te maken, die voor zijn toekomstig lot beslissen zal; ... neen, Hij schept de mensch, ook diens geheele geestelijk zijn van den aanvang tot het einde'.

(Gunning 1881:58)

Een mens kiest uit de voorhanden mogelijkheden, maar God stelt het wezen der dingen en handelt daarnaar. Kortom, 'God schept ons van den aanvang tot het einde van ons leven' (Graafland 1987:489). Om dit te verduidelijken wijst Gunning op ons lichaam, dat zowel oorzaak als gevolg van onze wilsuitingen is (Gunning 1903:83 en Gunning 1880 (IV):427).

Het doel is de vrije wil van de mens - het doel, zodat er geen reden is om Gunning ervan te beschuldigen dat hij te veel nuimte geeft aan de wil van de mens en daarmee in feite meer arminiaan dan gereformeerd te noemen is. Het is zelfs zo dat hij zich niet mengen wil in deze discussie, omdat hij een andere weg wil gaan. Hij meent dat zij meer en meer verstrengeld raakten in een strijd zonder uitzicht, omdat zij niet boven de physische opvatting van Gods almacht uitkwamen. Wanneer Graafland bij zijn voornoemde bespreking van de visie van Gunning opmerkt dat deze met zijn kritiek niet werkelijk de theologie van Dordrecht raakt omdat zij de vraag stelt naar de bijdrage van de wil aan de tot standkoming van het heil (Graafland 1987:489), dan zal Gunning antwoorden dat de gereformeerde kritiek hem niet raakt omdat deze kwestie in het kader van de ethische opvatting van Gods almacht niet aan de orde is. Zo merkt hij op: 
Ik loochen of bestrijd hun redeneringen niet, maar heb er eenvoudig geen oordeel over. Het eenige wat ik zeggen kan, is dat ik de majestueze, verleidelijke harmonie in hun beschouwingen niet voor de rijke verscheidenheid van gezichtspunten inruil, welke Paulus en Johannes, Jesaia, Jakobus en Mattheus, elk hunner onbevangen en eerbiedig gehoord, bij mij achterlaten'.

(Gunning 1880 (IV):428)

Dit voortdurende werk van God rust ten diepste in Gods eeuwige Raad. Dat te mogen weten, geeft zekerheid en rust voor de gemeente. Het is immers 'het voornemen der verkiezende genade Gods, dat het afgevallen, het in den dood liggende lichaam des vleesches tot de hoogste heerlijkheid op zou stijgen' (Gunning 1869 (III):219). Dat voornemen te kennen en te aanvaarden - dat wordt bedoeld met het kennen van de Vader (Johannes 14, 7), waardoor zowel ons leven alsook het leven van Jezus Christus geschouwd wordt tot op het hart van God in tegenstelling met een zien op 'Joodsche wijze' naar Jezus' leven en lijden (Gunning 1881:579).

Het hart van Gods eeuwige Raad is de eeuwige eenheid tussen de Vader en de Zoon. In de uitgave van Het kruis des Verlossers die Gunning kort voor zijn dood nog gereed gemaakt heeft en waarin hij opnieuw voor de gemeente de grote betekenis van het lijden en sterven van Jezus Christus wilde uiteen zetten, voelt hij zich gedrongen om alle schijnbare toevalligheid en ongerijmdheid aan Diens leven te ontnemen door te stellen dat er tenslotte sprake is van de uitvoering van Gods eeuwige Raad (Gunning 1904:23-26). Daarin heeft de Drieënige Zich voorgenomen om Zich met zijn schepping te verenigen en dan allereerst en op bijzondere wijze met haar hoofd de mensheid. Dáártoe was deze mensheid geschapen in het eeuwige Woord, waardoor wij uitverkoren zijn vóór de grondlegging der wereld. 'Dat is, de menschheid heeft een eeuwig bestaan in God! en daarom heeft God, in den Zoon, een eeuwige betrekking tot de menschheid' (Gunning 1869 (II):314).

Het is nodig, dat we erop letten welke betekenis Gunning aan het woord eeuwig geeft. In de eerste plaats duidt het op de grondslag van datgene wat eeuwig genoemd wordt. En dan mogen we denken aan het wezen van God dat eeuwige liefde is. Neem de bekering van Mattheus: 'Van geen van beide zijden is er vooruit bedacht, of worden vóór men besluit, inlichtingen ingewonnen. Dit heet van de zijde Gods verkiezing, roeping, van de zijde des menschen geloof, onweerstandelijkheid der genade. En wat nu zoo is, dat blijft ook zoo, want het is in de eeuwige Liefde gegrond' (Gunning 1881:590). 
Daarmee is alles wat eeuwig is, boven de tijd verheven en onafhankelijk van de voorwaarden van de wereld (Gunning 1903:82; 1884:102). Maar dat houdt tenslotte ook in, dat het eeuwige 'even zoo goed heden, op dit oogenblik, feit kan worden als op welk tijdstip ook' (Gunning 1880 (IV):427).

Gegeven de situatie van verlorenheid van de mens door de zondeval van Adam èn door de ongehoorzaamheid van Israël moest God zèlf ook als mens aan de voorwaarden van het eeuwige verbond met zijn schepping voldoen. Op grond van de eeuwige eenheid tussen Vader en Zoon 'gaf de Vader den Zoon als Middelaar over, en deed dus het volk des Middelaars in zijn volle liefde deelen; en met diezelfde liefde gaf de Zoon zich den Vader over, om Hem volkomen te gehoorzamen, en om zijn volk, in zichzelven, tot volkomen zaligheid te leiden' (Gunning 1904:24). Zo rust de verkiezing der gemeente in Christus op Gods eigen heilig wezen en werd de Zoon menswordend wat Hij van eeuwigheid reeds was: de grond der schepping, het Hoofd van de mensheid. Daardoor komt het hele verzoeningswerk van Christus te staan in het licht van de eeuwigheid. En dat geeft aan hen die gelooft, volstrekte zekerheid. Christus is immers niet slechts gekomen om aan onze behoefte van zaligheid te voldoen, maar veeleer om Gods eeuwige Raad tot uitvoering te brengen. Daarmee heeft $\mathrm{Hij}$ het hele reddingswerk op Zich genomen - van rechtvaardiging tot de volkomen verlossing in heerlijkheid. 'Ik kan niet meer verloren gaan in eeuwigheid, omdat God getrouw is en zijn verbond onverbreekbaar. Dit gelooven is: het tot mijn eigendom maken' (Gunning 1904:26).

Dat betekent voor Christus ook zekerheid en houvaast tijdens zijn vreselijke lijden, dat uitliep op godverlatenheid. Als Uitverkorene Gods, in Wie de eeuwige Raad zijn diepste gestalte krijgt, weet $\mathrm{Hij}$ dat de koning niet zonder onderdanen zal zijn (Gunning 1869 (II):315; vgl NGB art 27). Zijn werk zal niet kunnen mislukken, wanneer Hij slechts vasthoudt aan Gods Raad. Dit maakt ook duidelijk dat verkiezing tot zaligheid onlosmaaklijk verbonden is aan verkiezing tot dienst. Dat geldt zowel het Hoofd als de leden der gemeente. Wat Christus betreft: 'Zijn vereeniging met ons door de vleeschwording is zoo volkomen ernstig gemeend en waarachtig, dat indien de menschheid en de wereld ( $\mathrm{d}$ w z zij, die zich tot het ware levensbestanddeel der wereld laten vormen, want de anderen vallen als dorre bladen af, worden als kaf verbrand) - dat indien de menschheid en de wereld verloren kon gaan, de Zoon Gods meê zou verloren gaan' (Gunning 1881:89). De overgave van de Zoon is meer dan een mogelijkheid scheppen van verlossing, waarbij het zou kunnen blijken dat alles voor niets is geweest. Het is de verlossing zelf, waarbij elke willekeur uitesloten wordt. De gevolgen voor de leden van dat lichaam zien we bij voorbeeld bij Paulus: 'krachtens zijn brandende liefde zou hij zelf verloren gaan als hij de Gemeente, voor zijn deel, niet toebracht (1 Cor 9 , 
23.27). Hierin bestaat immers ook eens leeraars getrouwheid, hier ligt zijn drang tot worstelende voorbede: hij gaat zelf verloren indien de Gemeente niet behouden wordt' (Gunning 1881:90).

De eeuwige verkiezing, die tegelijk de eeuwige bestemming aangeeft van de mensheid, geeft aan het leven van de mens een geweldige ernst. Dat doel is: onder Christus, in den Heiligen Geest, evenzeer met God als onderling vereenigd op een nieuwe aarde, onder een nieuwen hemel als middelpunt van een verheerlijkt heelal te leven (Gunning 1884:106). Omdat God vrijmachtig is, zal Hij dat doel bereiken. Maar omdat het de vrijmacht der goddelijke liefde is, die in de gestalte van de Heilige Geest in ons hart en leven werkzaam zal zijn, hoeft een mens niet angstig door schuld en machteloosheid op te zien tot de Drieënige God, die zoveel van zijn schepsel eist. Wie in overgave opziet, zal ontdekken dat het juk van Gods bedoelingen het zachte juk der liefde is. Immers - 'in de liefde is de verzoening der vrijheid met de noodzakelijkheid' (Gunning 1869 (II):361). En dat is het, waartoe Christus ons nodigt: 'Mijn juk is zacht en mijn last is licht' (Mat 11, 28-30).

\section{DE BETROKKENHEID VAN DE MENS.}

Terwijl heel dikwijls in de teologie Gods verkiezing op gespannen voet staat met $\mathrm{Zijn}$ nodiging tot het heil, benadrukt Gunning dat de verkiezing nu juist de weg vrijmaakt voor de nodiging. Hij noemt deze geloofswaarheid herhaaldelijk het kanaal waarlangs het -reddingswerk zich ver en breed in een door de zonde aangetaste schepping kan realiseren, dat de mensheid is.

Uiteindelijk spreken we dan over het werk van de Heilige Geest, dat nooit gescheiden kan worden van dat van de Vader en van de Zoon maar wel een eigen betekenis heeft. De Geest is het die in ons doet wonen die met ons was. En wanneer dat geschiedt is er sprake van het ontstaan en de groei van de mens als persoonlijkheid (Gunning 1877:29).

Het gaat er dus om, dat een mens heel persoonlijk bij dat eeuwige werk van God betrokken wordt. De opdracht daartoe vinden we in 2 Petrus 1, 10: 'Beijvert u daarom des te meer, broeders, om uw roeping en verkiezing te bevestigen; want als gij dit doet, zult gij nimmer struikelen'.

Deze opdracht is in feite dezelfde als die tot geloof. Dat is een aanvaarden dat God de mens bij name noemt; het is doen bevestigen aan de enkeling tot in het grote goed dat in de gemeente in het doopverbond tot in het duizendste geslacht tot uitdrukking is gebracht. Die enkeling moet 'ik' dan zijn; en de naam is 'mijn' naam. 'Alzoo die den Vader en den Zoon in eeuwige liefde verbindt, en die ook ons in dezelfde liefde als schepselen met den Oneindige vereenigt' (Gunning 1869 (I):280). Daarbij beseft 
Gunning heel goed dat er in de huidige situasie wel niet onzekerheid bij de gemeente mag zijn, maar wel degelijk spanning en strijd die des te meer doet uitzien naar de toekomst des Heeren. Maar juist in relatie tot de Heilige Geest zijn die twee: zekerheid en uitzien onlosmakelijk verbonden.

In den Heiligen Geest vinden wij God niet alleen in wat Hij werkelijk is, maar in al wat wij kunnen begeeren, dat Hij ooit voor ons zijn zal. God is Heilige Geest, dat wil zeggen: God is niet alleen werkelijkheid maar ook Ideaal. Doch zijn hoogste ontplooiing kan altijd slechts toonen het geen $\mathrm{Hij}$ is, want Hij zegt voor alle toekomst gelijk voor het heden: Ik ben die Ik ben'.

(Gunning 1904:104)

Die spanning vindt zijn oorzaak in onze situatie en het is wellicht met name de zogenaamde ethische teologie die deze ernstig neemt en in zijn volle omvang probeert te peilen. $\mathrm{Zij}$ is er namelijk zo diep van doordrongen dat het God gaat om zijn betrokkenheid op het geheel van de schepping omdat daarin haar behoud ligt, terwijl de zondige mèns voortdurend bezig is om de hem toevertroude schepping zelf tot voltooiing te brengen met zijn verkregen kennis van goed en kwaad ondanks de waarschuwing dat deze inspanning met de beste bedoelingen toch slechts de dood ten gevolge heeft. Er is immers alleen maar leven waar de Here God leven geeft in de gemeenschap met Hem. Wanneer wij nu God slechts als onpersoonlijke, physische kracht bezig zien in zijn schepping, is er feitelijk geen onderscheid tussen wat Geest genoemd kan worden en onze natuurlijke krachten. Dan verstaan we Gods invloed op de schepping slechts op de wijze van natuurlijk werken. Weten we echter slechts op de wijze van natuurlijk werken. Weten we echter van de almacht der liefde, dan mogen en moeten wij een wezenlijk verschil aanvaarden tussen de Heilige Geest en de geest van de mens inclusief zijn natuurlijke krachten (Gunning 1869 (II):66 \& 98).

De situatie is echter ingewikkeld geworden door de zondeval van de mens. $\mathrm{Nu}$ is er sprake van moeilijk te onderscheiden werkingen van de Heilige Geest, hoewel dat onderscheid principieel wel aangenomen moet worden. 'Sedert de zonde in de wereld kwam, heeft de Geest wel voor het lichamelijke een levenwekkende, maar voor het vleesch eene verterende, doodende werking' (Gunning 1864:66).

Er is Gunning alles aan gelegen om dit onderscheid niet tot scheiding te laten worden. Daarom moet het werk van de Geest betrokken blijven op het Woord, op de Zoon van God. Er was alle gelegenheid om hierop nader in te gaan vanwege het ook toe algemeen verbreide verlangen - met name in de kerk - naar een geestelijke opwekking. 
Aanvankelijk schreef hij hierover in het blad De Vereeniging Christelijke Stemmen (1974) maar een jaar later voelde hij zich gedrongen dat artikel omgewerkt en uitgebreid uit te geven onder de titel 'Geestelijke Opwekking', omdat het nodig was de toenemende verwarring en onzekerheid een halt toe te roepen. De aanleiding tot dit schrijven was een opmerking van de inmiddels overleden D Chantepie de la Saussaye dat wij een nieuwe uitstorting van de Heilige Geest nodig hadden. Een andere oplossing voor de verdrietige situatie van de kerk in Nederland zag hij niet. Gunning kon deze noodkreet verstaan, maar waagde het toch te betwijfelen of een zogenaamd revival het antwoord zou zijn op de heersende kerkelijke nood met alle gevolgen voor land en volk. Afgezien van de reserves die hij heeft tegenover zo een beweging omdat er daarbij sprake is van een typisch engels verschijnsel dat in onze cultuur niet zo past, wijst hij vervolgens op een veel ingrijpender kenmerk van zulke bewegingen die ons zeer voorzichtig moet maken wanneer de oproep gedaan wordt te hopen op en te bidden om een opwekking als resultaat van een nieuwe uitstorting van de Heilige Geest. Dit verlangen getuigt in de eerste plaats van een groot tekort aan kerkelijk besef: 'De grote waarheid, dat de Heilige Geest in de gemeente is, dat $\mathrm{Hij}$ hoe ook onder ons tegengestaan, uitge-blust, verloochend, evenwel toch met zijn almachtigen werking onder ons blijft en in de gemeente woont, is ons geheel vreemd geworden' (Gunning 1875:11). Wat wij verlangen, lijk meer op het werk van Johannes de Doper dan op dat van Jezus. Zulk geestelijk leven heeft enerzijds het kenmerk van een revolutionaire omkering van een mensenleven maar anderzijds heeft het nauwelijks diepgang, laat staan een brede uit-werking. En dat is wat Jezus bedoelde. Het is Gunning trouwens opgevallen, dat deze vrome mensen vaak op maatschappelijk gebied fervente tegenstaanders zijn van elke revolutionaire ingreep!

Deze positie-bepaling ten aanzien van het geestelijke leven heeft twee kanten. Enerzijds wordt het natuurlijke miskend als individualisme en anderzijds wordt het natuurlijke miskend als de van God gegeven situatie waarin een mens gesteld is. 'Dit baptisme is een ontkenning van de natuurlijke ordeningen Gods' (Gunning 1875:13). $\mathrm{Er}$ is ook geen sprake van een meedragen van de schuld aan de ontstane situatie. Men gedraagt zich typisch als een logeergast. Maar ten diepste wordt in wezen de Drieëenheid geloochend, aldus Gunning.

Gunning wijst het ook af, dat er dit onderscheid gemaakt wordt tussen rechtvaardiging en heiliging alsof een mens wel gerechtvaardigd kan zijn zonder dat er nog sprake is van heiliging. Hij schrijft: 'Die zich in de Heiland alleen verlost, maar niet geheiligd weten, zijn niet bekeerd, slechts opgewerkt' (Gunning 1875:19).

Bekering houdt in de volstrekte overgave aan Christus die in beginsel de gemeenschap tussen de Drieënige God en zijn schepping hersteld heeft. De heiliging is de 
uitwerking, de realisering tot aan de grenzen van het menselijke bestaan van deze geloofsovergave aan het Hoofd. Daardoor is in beginsel ook het subjectivisme en het individualisme onmogelijk. In de practijk blijven zij echter voortdurend hèt gevaar voor het kerkelijk leven. Dat gevaar wordt werkelijkheid, wanneer men meent dat het eigenlijke werk van God pas begint in het hart van de mens. In dat geval is er altijd de dreiging van onzekerheid omdat men bij zichzelf te rade heeft te gaan. En deze onzekerheid kan alleen weg genomen worden door steeds nieuwe geestelijke ervaringen. 'Men bouwt dan op zijn eigen, min of meer levendig, geloofsleven en niet op de daad Gods in het Doopverbond' (Gunning 1875:22).

Bij de bespreking van de brieven van Paulus aan de Efeziers is Gunning hierop nader ingegaan. Hij spreekt ook dan van de baptistische dwaling, 'die niet Christus maar de Heiligen Geest tot Hoofd der gemeente stelt' en daardoor de natuurlijke ordeningen van God zoals deze bij voorbeeld tot uitdrukking komen in het gezag van ouders en overheden, verstoort. 'Maar aldus wordt weldra in plaats van den Geest in de gemeente, de gemeente zelve gesteld, de stem der gemeente voor de stem Gods gehouden, gelijk de strekking onzer dagen ook in de Hervormde kerkgemeenschap is' (Gunning 1869 (IV):314).

De uitweg naar geloofszekerheid en naar het leven van heiliging waarin de hele schepping participeren mag, ligt in dat gene wat Gunning enerzijds Gods verkiezing noemt en anderzijds de toekomst des Heren. En op dat fundament rust het zoeven reeds genoemde doopverbond. Door dit samenspel van goddelijke werkelijkheden kan bijeen gehouden worden, wat onder geen beding uiteen mag raken. Christus is het Hoofd van de gemeente en 'geestelijk leven is niet anders dan leven uit den Heiligen Geest, die ons Christus en aller Zijner weldaden deelachtig maakt, bovenal der mystische eenheid van Hoofd en Lichaam, van wynstok en ranken. - Dat leven neemt alles uit Christus en belijd en beleeft Hem alleen' (Gunning 1904:12). Dat betekent tegelijk strijd tegen de geest der behoudzucht; tegen de reactie-geest en tegen de partijgeest, aldus Gunning in deze Open brief. Op deze wijze regeert Christus zijn gemeente al is het in afwachting van de volkomen realisatie van de toekomst des Heren op een voorlopige wijze.

Geloven in Christus is dan ook hetzelfde als voortdurend bidden om het voortgaande werk van de Heilige Geest die aan de gemeente gegeven is. De individuele gelovige bidt mee in het geheel - ook met het oog op zichzelf, omdat hij dat geestelijke leven alleen bij God vinden kan èn omdat hij weten mag dat leven hem is toegezegd op een heel persoonlijke wijze bij de doop. Om die reden is het voor Gunning ondenkbaar, dat er niet gedoopt sou worden in de Naam van de Vader, de Zoon en de Heilige Geest. In die tijd werd daarover verschillend gedacht en op synode-niveau werd daar- 
over gediscusseerd. Het voorgestelde dopen in de naam van geloof, hoop en liefde bevestigt veelmeer het antwoord van de gelovige en zijn kinderen, maar dat is nu juist het baptisme dat Gunning verwerpt. Onze zekerheid ligt alleen in de gave en niet in het ontvangen van het Woord van de Drieënige God (Gunning 1865).

Voor de gereformeerden uit die dagen waren deze gedachten hoe indrukwekkend ook toch niet een bevredigend antwoord op de vragen die gesteld waren. Kuyper en de zijner hadden opnieuw het gevoel, dat Gunning (weer) niet inging op hun vragen die toch zeker ter zake waren. Bij voorbeeld deze: is Gods genade zo bezien toch niet meer algemeen dan particulier? Het was hem al eens gevraagd en Gunning had geantwoord op de hem typische wijze. Hij meende dat de vraag niet correct was. 'De genade is mij algemeen naar de ons geopenbaarde bedoeling Gods, particulier, helaas! naar de zichtbare uitkomst' (Gunning 1880 (IV):424). Meer hierover zeggen is voor ons mensen in de huidige situatie van leven bij Gods openbaring ongeoorloofd. Hij veroordeelt de nadere systematisering niet als onwaar, want zelfs die uitspraak ligt buiten onze mogelijkheden van kennen.

Een paar jaar later kreeg hij kennelijk uit eigen kring de vraag zo gesteld: Is de genade die wij ontvingen, particulier? In het bijblad van Pniel van 14 Juli 1894 is zijn antwoord: 'De genade welke de gemeente ontvangt, namelijk van in het Verbond Gods te zijn opgenomen, is tegenover de overige menschheid en de schepping particulier, maar tegenover elk lid der Gemeente algemeen, want allen zijn van God bedoeld'. Christus is de eeuwige Middelaar van de hele schepping en in het bijzonder voor de mensheid. Wanneer we verder nadenken en opmerkingen maken, moeten we dat niet doe als wijsgeer maar als gelovige 'en dan is het hetzelfde of iemand met Calvijn eene particuliere dan wel of hij met Luther eene algemeene verkiesing stelt'.

Binnen de gemeente zijnde moet een mens zich voor uitverkoren houden, omdat niet-in-Christus-geloven de grootste zonde is die maar mogelijk is (Joh 16,9). Wel kan hij sidderen, wanneer hij eraan denkt, hoe hij tekort schiet in dankbaarheid en dienen. Maar 'ook die vreeze wil Gods genade overwinnen.'

Gods Geest wil een mens betrekken bij Christus en zijn werk; hem deel geven aan de verkiezing, zodat deze het beginsel van zijn leven wordt; hem de hemelse Vader doen kennen; hem opnemen in Gods eeuwige Raad. Het zijn verschillende aanduidingen van het geloofsleven, waarbij de laatste het meest fundamentele uitspreekt. Van de mens vraagt deze betrokkenheid 'slechts' zelfverloochening. Omdat de mens zondaar is geworden, moet deze overgave de gestalte aannemen van kruisdragen door hoop: Een ieder, die deze hoop op Hem heeft, reinigt zich, gelijk hij rein is (1 Joh 3, $3)$. 
De keerzijde hiervan is de verheerlijking van Gods heiligheid, die van schrik tot troost geworden is voor ieder die gelooft in Christus. Door Hem wordt Gods recht gehandhaaf en daartoe heeft de Vader Hem aangesteld tot rechter over levenden en doden (Hand 10, 42). In de geschiedenis van Israël is Hij de onderwijzende en geduldige rechter; in Galilea de lokkende rechter; in Jerusalem de wenende rechter; op Golgotha de bloedende rechter en in de gave van de Heilige Geest de levendmakende rechter (Gunning 1904:103-104). Deze aanstelling 'heeft bij elk mensch ten doel, zijn natuurlijk leven te verbrijzelen; hem door vernietiging van zijn eigenbatige afzonderlijkheid in de groote menschheid in te lijven, tot mensch te maken, en wel bepaald tot dien bijzonderen mensch gelijk Gods voor Zijn Koningkrijk' (Gunning 1881:66).

Daarom sprak Ananias tot Paulus in èn adem van verkiezing en lijden (Hand 9). Gunning wijst er in dit verband nog op, dat er sprake is van trappen in de verkiezing. Zoals de ene ster meer schittert dan de ander, 'zoo zijn er eerstelingen die door lijden tot een eerder afleggen van den ouden mensch komen' (Gunning 1876:93). Het doel is echter voor ieder het-zelfde: een plek in de eeuwige Raad Gods, al heeft die plaats een persoonlijk karakter naar gelang de Here God met ons zijn bedoelingen heeft.

Dat leven uit de verkiezing heeft een aantal duidelijke kenmerken. We hoorden eerder van heldenmoed. 'Moed is de werking dezer verkiezing in ons gemoed' (Gunning 1876:66). Het is een leven vol troost. Het is een bestaan, dat zijn voltooiing vindt in het gebed. 'In het gebed toont zich het volkomenst, hoe de goddelijke daad de menschelijke wekt. Bidden is: zich volkomen door God bepaald weten, en aan het door deze bepaaldheid verloste, van elken invloed der wereld bevrijde, leven zijn natuurlijken gang laten. Die natuurlijke gang is aanbidding' (Gunning 1876:92). Zo zpreekt Gunning van de prediking der verkiezing als een Jordaan van genade. Het Hoofd der gemeente liet Zich daar dopen en daarna heeft Hij gebeden (Lucas 3, 21). Toen ging de hemel open en mocht Hij verder zijn taak volbrengen onder een open hemel. Wie zich aan Hem overgeeft, mag delen in dat gebed en in die weg van lijden tot heerlijkheid. Vervolgens zien we deze genade zich uitbreiden als watergangen, die vanuit de Jordaan gevoed worden. Het gebed wordt haast vanzelf een voorbidden, waardoor de gelovigen, de uitverkorenen organen worden 'door welke de werking Gods als door kanalen afdaalt tot de overigen' (Gunning 1881:68). En zo wordt het waar, dat God de wereld regeert door de gebeden van zijn kinderen, want gebedsverhoring is de kroon der wereldregering. Dan heeft de Here God het doel bereikt, dat Hij beoogde met zijn schepping. Nu blijkt, waartoe $\mathrm{Hij}$ in staat is: 'Gods hoogste macht is, dat het Hem gelukt wezens te scheppen die vrij worden, die uit eigen beweging in Zijn wegen ingaan, en begeeren en vragen wat Hem behaagt' (Gunning 1881: 68). 


\section{ECHT GEREFORMEERD?}

Op de lippen van de gereformeerden brandt nog steeds die ene vraag, ja meer dan ooit. En het antwoord zal beslissen over het uiteindelijke oordeel over dit getuigenis van de geloofswaarheid der verkiesing. Maar ... moet het eigenlijk nog gevraagd worden? Is het antwoord niet bekend? Gunning leert immers de algemene verzoening?

Het uitgangspunt is duidelijk en staat onwankelbaar vast: ten aanzien van de mensheid mag met het oog op Christus gezegd worden: 'In de diepte van 's menschen wezen ligt het eeuwige Woord, aanduiding van zijn verkiezing en bestemming' (Gunning 1881:460). Anders gezegd: 'Ons burgerschap is in de hemel, ... omdat wij der hemelsche heerlijkheid van den eersten aanvang af toebehooren, omdat $z \mathrm{ij}$ in ons is de verborgen, maar in den strijd der heiliging steeds meer en meer te voorschijn tredende grond onzes nieuwen geestelijken levens' (Gunning 1869 (II):308).

Maar juist de verkiezing duidt aan, dat het in dat geheel om de enkeling gaat: een persoonlijke relatie met God en daarin een persoonlijke opdracht, zoals de gelijkenis van de talenten bij voorbeeld duidelijk maakt. Met name in de doop wordt deze indrukwekkende roeping aan de enkeling bevestigd: 'hij is het begin van al die leidingen des Heeren, door welke de gelovige van zijn eeuwige verkiezing verzekerd wordt' (Gunning 1902:16). Samen vormen al die leidingen de vrijmacht Gods, die daarin vooral tot uitdrukking komt, 'dat alle tegenstand dien vriend of vijand tegen Gods voornemen opwerpt, Hem niet verhindert zijn einddoel te bereiken' (Gunning 1881: 62). Met verrassing mag dat soms geconstateerd worden zoals eens in Antiochië: 'En allen die bestemd waren ten eeuwigen leven, kwamen tot geloof' (Hand 13, 48). Dat wil zeggen volgens Gunning: 'Van degenen die ten eewigen leven verordend waren bleven niet, gelijk bij Israël, zeer velen achter, maar niet è̀n' (Gunning 1869 (IV): 133).

Zij kwamen tot geloof en dat is: 'Kortom de belofte, de verkiezende genade Gods, in den geloove vastgehouden, tegen hope op hope geloofd, tot leidend beginsel des levens gemaakt' (Gunning 1869 (IV):61). Maar nu blijkt, dat Gods doel bij de meeste mensen niet bereikt word. Wanneer dàt de reden is, dat soms geleerd word, dat Christus' verzoeningswerk alleen voor de uitverkorenen is geweest, dan wil Gunning deze ketterij nog wel aanvaarden (Gunning 1873:24). Maar het is beter het zo niet te zeggen, want God wil dat alle mensen zalig worden. Maar toch wil Hij kennelijk niet onvoorwaardelijk zijn doel bereiken. Dan echter gaat het om zijn betrokkenheid bij iedere afsonderlijke mens en daar blijft een onbegrijpelijkheid (Gunning 1869 (II):365). Op dat punt van zijn betoog waarschuwt hij herhaaldelijk voor filosofie, voor menselijk pogen met zijn verstand het ondoorgrondelijke toch te doorgronden. Daarvan beschuldigt hij bij voorbeeld Calvijn. Tenslotte meent men het laatste woord gesproken te 
hebben door te wijzen op twee willen in God, twee eigenschappen (rechtvaardigheid en barmhartigheid), tweeërlei verkiezing. En het laatste woord is: 'Zijn soevereine wil verklaart alles' (Gunning 1881:64).

De gemeente echter weet alleen van zaligheid, omdat zij in het geloof op Christus ziet. 'Alleen in het leven leeft zij, den dood heeft zij achter den rug, en kan hem dus niet zien noch beschrijven. Alleen het licht, maar de duisternis is haar duister' (Gunning 1881:65). Alleen met een afgewend gelaat zal zij iets zeggen over wat daar gebeurt en hoe dat mogelijk is, omdat zij weet wie zij in zich zelf is.

Het blijkt dus mogelijk, dat mensen niet in Christus geloven, Hem zelfs haten. Er zijn er die zich afzonderen uit het geheel, dat rusten mag op het werk van schepping en verzoening van het Woord. 'Zware straf komt over hem die het bloed des verbonds, waardoor hij geheiligd was, onrein geacht heeft door het niet te gelooven' (Gunning 1894:bijblad). En zo zal het gebeuren, dat straks het koninkrijk van God engere grenzen zal hebben dan de gemeente (Gunning 1869 (IV):319). Buiten die grenzen is er slechts duisternis en dood, maar voor de mens als beelddrager Gods, als bij name genoemd is dat een heel bijzondere situatie. Wanneer hij Gods liefde versmaad, zal hij door deze liefde vernield worden. De onbeschrijfelijke grootheid van de mens houdt in, dat 'er nooit een geheel volstrekte scheiding tusschen God en den mensch kan zijn en die band zal juist de inwendige kwelling des rampzaligen wezen' (Gunning 1869 (IV):416u). Omdat God liefde is, is er voor de goddelozen eeuwige pijn (Gunning 1869 (II):176).

De eerste Adam heeft met volstrekte noodzakelijkheid al zijn nakomelingen meegesleept in zijn val, maar de tweede Adam, Christus in Wie Gods eeuwige liefde gestalte heeft gekregen, wil niet dwingen. Zo groot is de verdraagzaamheid tegenover de mens, zo respectvol is zijn liefde, dat het een mens mogelijk is verloren te gaan. Die zich niet geeft aan Christus, valt af en wordt niet meer door God gekend, op de wijze zoals Hij de weg der rechtvaardigen kent (Ps 1).

En toch is dit nog niet alles. Er blijft immers een relatie, zoals we zoeven zagen. Het roepen gaat door, het kloppen houdt niet op. Wanneer echter een mens weigert open te doen, zal dit werk van God een stuwen worden naar de ondergang. En aan het einde zal blijken, dat Gods genade inderdaad het karakter heeft gekregen van onwederstandelijkheid: zowel de geredde als de verlorene wil niet anders meer dan of behouden worden of verloren gaan, maar ten aanzien van de ongelovige heeft de genade de gestalte aangenomen van toorn (Gunning 1884:108 \& 1888:81).

Een laatste vraag is: maar Gods liefde zal deze situatie toch niet altijd laten voortduren? Dat zou betekenen, dat er een plek in Gods grote schepping is, waar het kwaad eeuwig God zal kunnen weerstaan. Is dat niet in strijd met zijn almacht der liefde juist 
als almacht? In de eerste plaats antwoordt Gunning, dat de beantwoording van deze vraag buiten ons gezichtveld ligt. Zowel ja als nee is ontoelaatbaar. Maar vervolgens wordt hij gedwongen te zeggen, dat juist het ethisch karakter der waarheid de vrije almacht terugbrengen op het niveau van het physische. En dat is verschrikkelijk. 'Wij durven als verkondigers van gods Woord niet zoo onbarmhartig zijn om dit ( $\mathrm{d}$ i een eeuwig verderf) te loochenen (Gunning 1892:87). We moeten trouwens bedenken, dat 'indien het kwade het kwaad is, dit is volstrektelijk niet door God gewild, dan is zijn bestaan ook voor èn oogenblik even ongerijmd als zijn altoosdurend bestaan' (Gunning 1884:67). Laat ons laatste woord hierover inderdaad zijn: ons bestaan hangt enkel af van Gods eeuwige verkiezing.

Het is de kern van het gereformeerde belijden. Hoe Gunning het zag, heeft hij al in een brief aan een vriend in 1863 kort samengevat:

Ontdoe de leer der verkiezing van de scholastieke vormen die haar ook bij Calvijn nog aankleven. Verbeter haar naar de Heilige Schrift. Neem diensvolgens in aanmerking dat "eeuwig" niet wijst op een eindeloozen tijd vò̀r en nà den tijd. Maar op datgene wat boven den tijd verheven is. Voorts, dat Gods almacht, als zijnde die der heiligde Liefde, niet is de beperking of vernietiging maar de schepping der menschelijke vrijheid. Overweeg, dat zaligheid en ramszaligheid niet is een toestand die tot den toekomenden staat beperkt is, maar een zoodanige die betrekking heeft op alle voorafgaande en voorbereidende toestanden van 's menschen geestelijk en stoffelijk leven. Vat, alsmede naar den eisch der Schrift, de "verwerping", het decretum horribile, veel. strenger en schrikkelijker op dan onze vaderen deden, namelijk niet als een meer of in fatalistisch "laten" in een toestand waarin God de menschen zou hebben gevonden, maar als een veroorzaken van hun verderf juist dór de werking Zijner liefde, daar toch een volhardend versmaden van geschonkene liefde de vatbaarheid voor de zaligheid uitdooft. Vergeet bovenal niet dat alle verkiezing alleen is om Christus den Uitverkorene, zoodat alles hangt aan het al of niet aannemen van $\mathrm{Zijne}$ genade in den geloove. In èn woord, vat deze leer, naar den eisch der Schriften, wel in den geest onzer Vaderen op maar tienmaal strenger en meer bijbelsch. dan zij het deden, dan blijkt de hoofzaak en kern van die waarheid dit te wezen: dat God met den mensch in persoonlijke, onmiddellijke gemeenschap treedt door de levenwekkende roeping Zijner genade, waardoor alle fataliteit verbroken en de ware vrijheid in de bekeering te voorschijn 
geroepen wordt. Met andere woorden, dit is de belijdenis van Christus in ons wonende door den $\mathrm{H}$ Geest, op grond van hetgeen Hij voor ons gedaan heeft.

(Gunning 1863:19)

Zo is er geen sprake van een angstig raadsel, maar de verkiezingswaarheid is de verrukte terugblik van den geloovige op alles wat hem tot aan dit punt, waar hij knielend in het stof aanbidt, is wedervaren '(Gunning 1884:96)).

\section{Literatuurverwysings}

Beker, E J \& Den Boer, M G L 1979. J H Gunning jr, een theologish portret. Baarn. Bos, G 1981. Christus de gekruisigde voor en in ons. Dordrecht: Uitgeverij J P van den Tol.

Graafland, C 1987. Van Calvijn tot Barth: 's-Gravenhage: Uitgeverij Boekencentrum BV.

Gunning, J H 1863. Geloof en Kerkworm.

1863. Vorm en Geest. Brief aan een vriend over onze kerkelijke toestand.

1864. Twee wegen een doel.

1865. De heilige doop.

1867. Zestien stellingen.

1869. Blikken in de Openbaring I tot IV.

1869. Kennis der sonde in Het eeuwig Evangelie.

- 1869. Laat ons een zijn met elkander, in De Vereeniging Christelijke Stemmen.

1873. De heilige schrift Gods woord.

1875. Geestelijke opwekkingen.

1876. Godskennis in Studien.

- 1876. Spinoza en de idee der persoonlijkheid.

1877. Het ethisch beginsel der Theologie.

1878 \& 1880 . Het ethisch karakter der waarheid (I tot VI), in Stemmen voor Waarheid en Vrede.

1879. Overlevering en Wetenschap.

1881. Van Calvijn tot Rousseau.

1882. Maria-beeltenissen in de katakomben, in Stemmen voor Waarheid en Vrede.

1884. Jesus Christus, de Middelaar Gods en de menschen.

1886. De opstanding des Heeren, in Woorden des eeuwigen levens. 
Gunning, J H 1886. Woorden de eeuwigen levens.

1888. De leeraarsbediening en haar voorecht, in Woorden des eeuwigen levens.

1888. De prediking van de toekomst des Heeren.

1890. Gerechtvaardigt en verheerlijkt, in Woorden des eeuwigen levens.

- 1892. Geen Middelaar als tusschenpersoon maar onmiddelijke gemeenschap met God, in Pniel.

- 1892. Wat is het geloof?

- 1893. Bedenkelijke voorbeelden, in Pniël jrg II

1894. Anarchisme.

1902. Verlagen wij onszelven niet.

- 1903. De eenheid des levens naar Spinoza's Amor intellectualis.

- 1903. Leven van Jezus.

1904. Het kruis des Verlossers.

1904. Open brief aan de synode der Ned Herv Kerk. 